Article

\title{
Forecasting Stability or Retreat in Emerging Democratic Regimes
}

Snigdha Dewal ${ }^{1}$, Jack A. Goldstone ${ }^{1,2}$ and Michael Volpe ${ }^{1}$

${ }^{1}$ School of Public Policy, George Mason University, 3351 Fairfax Drive, 5th Floor, MS 3B1, Arlington, VA 22201, USA;

E-Mails: sdewal@gmu.edu (S.D.); jgoldsto@gmu.edu (J.A.G.); mvolpe2@gmu.edu (M.V.)

${ }^{2}$ Russian Presidential Academy of National Economy and Public Administration, Vernadskogo prospect 82,

119571 Moscow, Russia

\section{How to Cite this Article}

Dewal, S., Goldstone, J. A., \& Volpe, M. (2013). Forecasting Stability or Retreat in Emerging Democratic Regimes.

Politics and Governance, 1(1), 32-47.

\section{Acknowledgement}

This Article was published by Librello, Politics and Governance's former publisher.

\section{About the Journal}

Politics and Governance is an innovative new offering to the world of online publishing in the Political Sciences. An internationally peer-reviewed open access journal, Politics and Governance publishes significant, cutting-edge and multidisciplinary research drawn from all areas of Political Science.

www.cogitatiopress.com/politicsandgovernance

\section{Editors-in-Chief}

Professor Andrej J. Zwitter, Faculty of Law, University of Groningen, The Netherlands

Professor Amelia Hadfield, Department of Psychology, Politics and Sociology, Canterbury Christ Church University, UK

\section{Managing Editor}

Mr. António Vieira, Politics and Governance, Cogitatio Press, Portugal 


\title{
Forecasting Stability or Retreat in Emerging Democratic Regimes
}

\author{
Snigdha Dewal ${ }^{1}$, Jack A. Goldstone ${ }^{1,2, *}$ and Michael Volpe ${ }^{1}$ \\ ${ }^{1}$ School of Public Policy, George Mason University, 3351 Fairfax Drive, 5th Floor, MS 3B1, Arlington, VA 22201, \\ USA; E-Mails: sdewal@gmu.edu (S.D.); jgoldsto@gmu.edu (J.A.G.); mvolpe2@gmu.edu (M.V.) \\ ${ }^{2}$ Russian Presidential Academy of National Economy and Public Administration, Vernadskogo prospect 82, \\ 119571 Moscow, Russia \\ * Corresponding author
}

Submitted: 8 January 2013 | In revised form: 8 March 2013 | Accepted: 10 March 2013 |

Published: 6 May 2013

\begin{abstract}
Drawing on the literatures on elite transitions, factionalism and the new institutionalism, this paper hypothesizes that the stability of partially democratic and emerging democratic regimes is dependent on the willingness of elites to make credible commitments to cooperate and comply with democratic rules. That willingness (or lack thereof) can be signaled by the presence of cooperative or conflict-precipitating events and actions in the periods around elections. We identify and analyze a variety of intra-elite interactions and demonstrate that conflict-precipitating events significantly increase the odds of a democratic retreat in the months before or just after an election, while cooperative events can balance them and prevent retreat. Using event data collected from 40 low- and middle-income countries for two-year periods around national elections between 1991 and 2007 we show that the imbalance of conflict-precipitating over cooperative events is far greater in cases of retreat from democracy. Furthermore, international intervention and pressure had a negative relationship with democratic stability. A logistic regression model accurately identified democratic retreat in 79 percent of the cases examined. Factor analysis revealed several common patterns of intra-elite conflict that can lead to democratic retreat, or conversely, patterns of cooperative events that bolster democratic consolidation. Finally, the data strongly argues for a model of democratic development that depends on open-ended elite maneuvering and the emergence of elite agreements, rather than a model where strong prior institutional constraints determine elite actions.
\end{abstract}

Keywords: conflict; cooperation; democracy; elites; institutions; opposition; stability; violence 


\section{Introduction}

Progress toward democracy is usually considered desirable-except for the problem that partial and emerging democracies have long been flagged as particularly vulnerable to violence or collapse $[1,2]$. Elections are a particularly risky and uncertain time for emerging democracies, as they can lead to greater consolidation, or to the outbreak of violence against the government or to government repression of the opposition. This leaves political analysts with a puzzle -how to identify when partial and emerging democracies are making progress toward stable consolidation, and when are there signs that such regimes are heading toward turmoil?

This study explores whether any specific pattern of events surrounding elections in partial and emerging democracies forms a reliable indicator of the eventual fate of these regimes. In particular, we examine the role of intra-elite interactions as signals of underlying patterns of relationships that may prevent or precipitate violence or further retreat from democracy. The elite groups examined include the ruling party, the dominant opposition and the military. This paper classifies various types of elite actions and events that indicate the presence or absence of formal and informal intra-elite cooperation and conflict, and then examines whether such events have a statistically significant relation to the continued stability, or the retreat from, democratic rule.

Democratic transitions have often been identified as arising from the development of cooperative arrangements or pacts among elites [3-5]. Numerous studies have explored the roots and dynamics of political instability in partially democratic regimes [111]. These studies have identified divisions among the elites as both a catalyst for democracy as well as a major cause of democratic retreats. However, this literature is lacking in three ways. First, it has not clearly specified the types of elite actions that lead to either regime collapse or stability. Instead, much of the focus is on the forging of agreements or pacts [35] or on elite adoption of specific institutions [12-14]. Except in hindsight, there is no way to tell if such agreements will hold or if compliance with the formally adopted institutions will last. Second, much of the study of elite factionalism and political conflict is undertaken in single-country case studies, providing a rich understanding of a country's conflict trajectory, but leaving unanswered the question of whether the same elite actions that contribute to democratic retreat or sustainability in one country would apply to other national contexts [15-17]. Finally, the literature on political conflict tells us much less about how to observe acts of elite cooperation than elite conflict, despite a growing recognition of the former's importance in maintaining regime stability $[3,18]$.

This research adds to our understanding of regime stability by improving our ability to identify and differentiate between cooperative and conflictprecipitating patterns of elite actions. A second aim is to enhance the effectiveness of intervention strategies in emerging democracies by accurately predicting instances when elections are likely to lead to further consolidation of, or retreat from, democratic governance.

\section{Theoretical Background}

To identify candidate events and actions that could indicate progress toward consolidation or democratic retreat, this study draws on insights from the literatures on elite theory, structural theories, factionalism and the new institutionalism. Elite theory as laid out by classical theorists like Pareto, Mosca and Michels focuses on the pre-eminence of a small and organized minority in key governance and nongovernance positions, determining the fates of the larger unorganized minority. The elites in this paper for the most part are those whom Mosca calls the "political classes". These elites are an inherent feature of almost all societies and systems, whether they are effective regimes, dysfunctional democracies, or primitive autocracies. Elite theory sees the interactions among elites-whether cooperative or conflictual-as the essential determinant of whether institutional arrangements will prove stable or not [3].

The structuralist school of thought regarding democratic transitions stresses that elites are bound by context; that is, democratic transitions come about as a result of changing economic structures that create divisions within the old dominant elites that lead to regime collapse $[19,20]$. Transitions to democracies occur when new elite alignments arise in which elites cooperate in maintaining the rules of democratic competition. Structuralists also emphasize that powerful nations wield significant influence over elite dynamics and democratic transitions in less powerful states $[19,21]$.

The literature on factionalism argues that countries with high levels of factionalism have high risks of regime instability and violent conflict. Factionalism reflects the presence of parochialism (a focus on group interests rather than national issues and interests), polarization (intense conflict in a winnertake-all, hostile environment), and violent factional mobilization $[22,23]$. Scholars of factionalism believe that international intervention is often the only way to change or influence elites' political actions. As Keefer and Knack [24] note, "in situations where political systems are highly polarized...a political stalemate between the two groups develops and, unless a force emerges that encourages cooperation [the stalemate] will prevent the development of coherent policy until one group emerges victorious or until the divisions shake the polity apart".

From the new institutionalism perspective (e.g., [25]), the concept of credible commitments forms the lever that either reduces or strengthens factionalism. 
Credible commitments are formal and informal interactions among political competitors that ensure that factional interests are protected, that parochialism is overcome by compromise, and that polarization is avoided. Positive interactions entail the perception of fair treatment and a mutual commitment to resolving issues through established channels, irrespective of which group holds official power. Compensation to elite ruling coalitions for withholding coercion and allowing stability to exist within the state comes in the form of political and economic rents, which are shared among the members of the coalition. The status quo is threatened when new groups demand a share in the rents and a role in the ruling coalition. North, Wallis and Weingast argue that the government's failure to make or keep its credible commitments to maintain stability and sharing economic and political rents increases the odds of a regime collapse. Other institutionalist approaches similarly argue that long-established patterns of cooperative behavior rooted in colonial or legal traditions reflect agreements and pay-offs that promote intraelite cooperation and thus maintain democratic institutions $[12,13,26,27]$. Goldstone and Ulfelder [18] argued that "the key to maintaining stability appears to lie in the development of institutions that promote fair and open competition, avoid political polarization and factionalism, and impose substantial constraints on executive authority".

All of these theoretical perspectives argue for the importance of elite actions-whether shifts in alignments, agreements, commitments, or polarization and conflict-in shaping the progress toward democracy. Yet all also tend to take a long-term view of change, showing how differences emerge across decades or even centuries. This is of little help in identifying, as an emerging democratic state approaches its early national elections, whether any newly forged elite agreements or newly adopted institutions will hold. Certainly some countries that were not blessed with a long history of favorable institutions have made successful transitions to stable democracy, including Greece, Spain and Portugal in Europe, Brazil and Colombia in Latin America, South Korea and Indonesia in Asia, to name just a few. Yet other countries appeared to have adopted sound democratic institutions, but failed to sustain them and went into democratic retreat, such as Chile in the 1970 s, or Nigeria several times reverting to military rule, as just two examples. Our goal in this paper is primarily empirical; we ask: among low-income emerging democracies, does the evidence regarding elite interactions around national elections reveal any particular patterns, or are there any specific cooperative or conflictual events or actions, that are significant predictors of later stability or retreat?

Yet our analysis also lets us address theoretical issues. If the new institutionalists are correct, and democratic progress rests on strong institutions 'tying the hands' of elites to prevent conflictual actions, then in the period around elections in countries moving to stable democracy we should see very few conflictual actions and almost entirely cooperative events and actions, as the institutions shape behavior. Countries lacking strong institutions to bind elites would conversely show mainly conflictual behavior, as elites maneuver to grab power and elections are just another occasion for power struggles. By contrast, if the theorists of democracy as emerging from hardwon elite bargains and evolving agreements are correct, so that elites retain great autonomy and have to decide whether or not to cooperate in upholding democratic institutions, we expect that the period around elections in emerging democracy would show a combination of conflictual and cooperative events, with the balance shifting somewhat toward cooperation where stable democracy develops, but shifting toward conflict where democracy breaks down. We can thus shed light on the institutional constraints vs. elite bargaining paradigms by asking: are different outcomes associated with clear patterns of predominantly conflictual or cooperative behavior?

We also can address the structuralists' claims about the importance of international intervention-when we add international efforts to reinforce democratic behavior to the mix of elite interactions and events, how significantly do such efforts shift the odds for stable democracy in the near future?

Thus this paper asks three empirical questions: Do any specific elite actions or events observed around national elections in low-and middle-income states show a significant tendency to portend future democratic stability or retreat? Does the mix of cooperative and conflictual events observed around such elections indicate strong effects of institutions creating predominantly cooperative or predominantly conflictual settings, or does the mix reflect more fluid and closely balanced settings in which elites appear to be moving back and forth toward settlements? Does international intervention around national elections make a significant difference in promoting stable outcomes?

\section{Data and Methods}

These questions were addressed by developing typologies of conflict-precipitating and cooperative events, and counting the various types of events that occurred in 40 partial democracies in the eighteen months before and six months following national elections for either national legislatures or national executives between 1991 and 2007. The partial democracies were selected, as described in more detail below, to include counties that both sustained democracy for years after their elections, and countries that failed to do so. The countries and periods studied in this research are shown in Appendix 1. 


\subsection{Independent Variables}

From a review of the literature on democratic transitions, factionalism and the new institutionalism, we identified 23 discrete types of events and actions involving elites. We began with 11 "conflict-precipitating" and 12 "cooperative" events/actions. A "conflictprecipitating" event or action is described as one that initiates or heightens hostility, conflict and tensions between opposing parties and reduces the scope for mutual trust and cooperation. A "cooperative" event or action brings parties previously hostile, in conflict or not cooperating to a greater level of mutual trust and cooperation.

We do not distinguish between "actions" and "events", as the events we are observing are usually just the outcomes of prior elite actions. Some observers might treat a boycott of elections as an event; others as an action. The arrest of an opposition leader is an event, but it is also an action by the ruling elites. Our goal was to identify events or actions that could be given a specific date and place and identified from news accounts regarding a country in the months leading up to and following a national election. Thus, every time a riot is reported, a conflict event is recorded; we divide these events into two categories-those that draw little or no response from the government, and those that draw a strong military response from the government. A full description of all identified cooperative and conflict-precipitating events and actions is given in Appendix 2 [28].

Information on the occurrence of cooperative and precipitating events and actions was obtained from an examination of local and international print media over a two-year period for each country revolving around a potentially contentious upcoming national election. The time period stretches from 18 months prior to the election to six months following the election. Elections present a critical opportunity for change in the political system. It is around election time that the opposition is most vocal and looking to strengthen its support base, while the ruling party is reactive and attempting to maintain its supremacy. Interactions in the months leading up to an election, or in the months immediately following, when results may be contested, offer ample opportunity for both government and opposition leaders to signal whether they intend to cooperate with opponents or not.

We found that, as the time before or after the election date increased, fewer elite actions or events occurred. Once the data had been coded, we discovered that within the 18-month period prior to an election, an average of 7.003 months passed before the first event was coded. Furthermore, in the sixmonth period following the election, we found that an average of 4.55 months passed between the last coded event following the election month, and the end of the six month period. What this shows clearly is that the vast majority of identified elite actions and events took place within the period from one year before to two months after the election. The further one stretches the time frame, the steeper the drop off in the observed cooperative and conflictual events.

Two coders populated the dataset, checking for the presence of any of the identified events in a monthby-month examination of media accounts of state politics. A sample of results was replicated by each coder to ensure inter-rater reliability of the coders.

Those events that did not occur at all in the groups of countries analyzed, or were observed in only a handful of instances, were omitted from the list of variables. For cooperative events, the resulting refined list included seven (out of the original twelve) cooperative events. Five were internal events: Bringing the opposition into the government (BringOpp), concession or agreement by government leaders to accept or act on opposition demands (ActOnOpp), a big win by either the regime or the opposition in a free and fair election (BigWin), explicit negotiations between government and opposition leaders to resolve disputes (ExplNeg), and agreement of a regime leader to step down prior to the scheduled election, usually to clear the way for another candidate (StepDown). Two types of international interventions were observed: international intervention to promote free and fair elections (Interv) and international pressure for reconciliation and fair play (IntPres). All of these events could be seen as changing the calculus of political actors in the direction of democratic stability. BringOpp, ActOnOpp, ExplNeg, and StepDown all indicate that ruling groups are willing to make a constructive, compromising response to demands of the opposition. BigWin, Interv, and IntPress all indicate to both ruling and opposition groups that either the electorate or the international community is strongly committed to backing fair and cooperative conduct.

A similar refinement was undertaken with conflictprecipitating events, as we set aside those that were not or only rarely observed in the cases investigated. The resulting six (out of the original eleven) events were: No action by the government in response to opposition protests (NoAction), extremely harsh military actions against a guerrilla rebellion, opposition group or protestors (MilExt), political acts by the opposition to undermine the elections or the ruling regime, such as boycotts, assassinations or refusal to accept election results (OppActs), constitutional struggles in which groups contest key rules of the game, challenging or seeking to change the constitution (ConstStr), coercive acts by the regime to undermine or hinder the opposition from fairly contesting an election, such as arresting or assassinating opposition politicians or banning an opposition party (ContrlOpp), and guerrilla or terrorist acts by the opposition (VioActs).

\subsection{Dependent Variables}

We started with a group of 14 cases identified in the 
Political Instability Task Force Problem Set [29] that experienced a major democratic retreat or instability within a year of scheduled elections (before or after) between 1991 and 2007. These constituted our cases of democratic retreat centered on elections. In each of these cases, there occurred a retreat from democracy, defined as any of the following conditions being met: There is a successful coup, the regime indefinitely postpones or cancels an election, or the regime outlaws the opposition or disqualifies it from participating in an upcoming election.

We began with 1991, because the period following the end of the Cold War created a new world, reflecting rapid changes in global power as well as regimes. Focusing on the post-Cold War era gave us a more consistent time frame in which to test relationships. We ended with elections no later than 2007, because we wanted to be able to check our work for longer event horizons - up to two years beyond the elections, and when we began this research in late 2010, complete data was only available through 2009. However, as we noted above, stretching out the time frame provided few or no important additional events -all the 'action' appears to take place in the months immediately before and after the scheduled elections. The chosen period of 1991-2007 also offered reasonably complete and accessible information on political events from on-line references such as Keesing's World News Archive and LexisNexis, and a manageable number of cases for coding.

We then selected a random sample of 26 countries (roughly twice as many as the problem cases, since the former are relatively rare) from those low and middle-income countries (GNI/capita under $\$ 10,000$ in constant 2000 U.S. Dollars) that held national elections between 1991 and 2007, and did not experience a democratic retreat within the two years following their election. We restricted ourselves to low and middle-income countries because of Przeworski et al.'s [6] finding that high income democracies do not retreat from democracy; we wanted comparison cases in which such a retreat was possible, but did not occur. In three of these countries, two national elections were held during this period; we thus ended up with 29 cases of elections that did not lead to a democratic retreat.

In this paper we refer to the 14 country cases in which a retreat from democracy occurred around a scheduled election (either in the twelve months before or after) as the "retreat" cases. The "no retreat" cases consist of 29 elections in 26 countries, in which no such retreat occurred in a similar twenty-four month period bracketing the election.

The countries we examined had Polity IV regime scores that varied widely, ranging from -7 to +10 on the Polity IV scale during the period of analysis. Figure 1 shows the trajectories of the average Polity scores for the retreat and no retreat cases over a four year period: two years before, the year of, and the first year after the observed elections.

As can be seen from the graph, for both sets of countries-the retreat and no retreat cases-the average Polity score over the observed period was 2.6. In other words, most of the countries were indeed emerging democracies, with Polity scores barely above the zero point separating democracies from dictatorships. However, while the no retreat countries started, on average, with a negative polity score, they ended with a positive score. By contrast, the retreat countries started with an average polity score of +4 , but declined by nearly seven steps over the four years we observed them to an average score of -2.71 .

In some of the democratic retreat cases, such as Armenia and Thailand, there were very dramatic declines in the Polity scores from high positive values (7 and 9) to large negative values ( -5 and -6$)$. Moreover, violence often flared or intensified-in six of the fourteen cases of democratic retreat, civil wars were started, resumed, or intensified in response to the calling or miscarriage of elections.

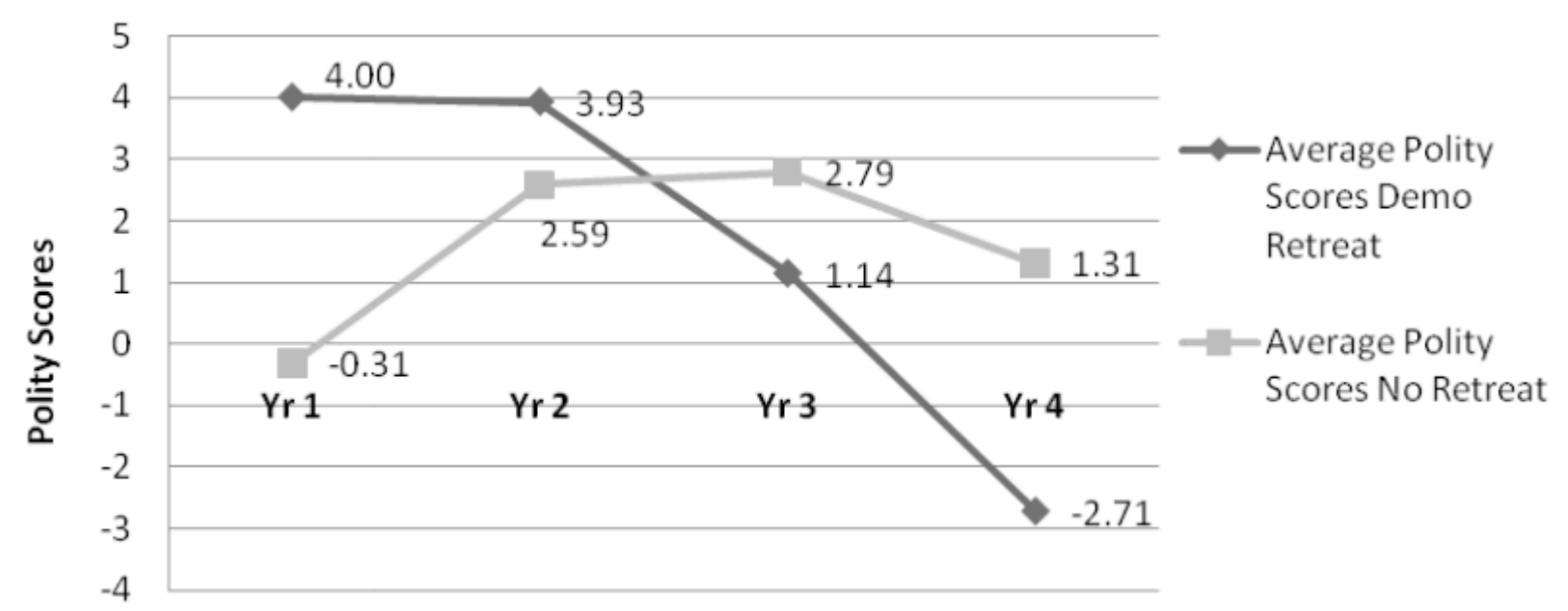

Figure 1: Polity movement across all cases. 
For most no retreat cases, the difference between the Polity scores for countries at the beginning and end of their analysis period was either zero or a small positive gain, indicating that there was a continuation of the status quo rather than significant progress. In many cases, the prevailing situation was far from ideal. Some no retreat countries-Mauritania, Djibouti, Guinea, Chad and Tunisia-had scores that were consistently negative, ranging from -7 to -2 . These regimes may have been only partially democratic, but even in unpromising circumstances they were able to hold elections with some opposition participation and experienced no marked retreat from democratic processes or collapse of government institutions.

\section{Analysis and Results}

For our initial analysis, we explored the relationship of the individual cooperative and precipitating events to the retreat and no retreat outcomes using Chisquared tests. We found five of the six common conflict-precipitating events to have a statistically significant positive association with democratic retreat at the 10\% level: NoAction, ConstStr, ContrlOpp, OppActs, and VioActs. (ContrlOpp, OppActs and VioActs were also significant at the $5 \%$ level.) These events therefore act as indicators of a coming democratic failure, presumably by showing that the ruling coalition and/or the opposition will not work with each other in ways that respect legal processes and promote stability.

We found that only two cooperative events, AcceptDef and IntPres, had a statistically significant relationship with democratic retreat at the $10 \%$ level. Interestingly, the effect of IntPres was negative, as it was observed more frequently in cases of democratic retreat. Indeed, we found to our surprise that several of the cooperative variables occurred more frequently in the retreat cases than in the no retreat cases.

As we demonstrate below, this was because the cases of democratic retreat had both a higher level of cooperative events and a much higher level of conflictual events. It appears that cases with high levels of conflict also elicited a large number of cooperative actions as efforts to respond to the conflict. This higher volume of cooperative events in cases of democratic retreat meant that several of the cooperative events and actions showed an unexpected, positive relationship to democratic retreat when examined individually.

It is therefore necessary to examine the joint effects of the two kinds of events and actions and their relationship to democratic outcomes. Figure 2 presents these findings, showing the average number of conflict precipitating events, the average number of cooperative events, and the difference between them for both the democratic retreat and the no retreat cases.

It is quite striking to see how much the difference between the number of precipitating and cooperative events differs in the two groups of countries. In countries where a retreat from democracy occurred, we observed on average 2.6 more precipitating events than cooperative events; where no retreat occurred the difference went in the other direction, with on average 0.3 fewer precipitating than cooperative events. The magnitude of the difference between conflict and cooperation appears to be crucial in whether democratic retreat occurs.

This difference is driven mainly by the incidence of conflict-precipitating events and actions. There was a significantly higher average number of conflictprecipitating events in countries with democratic retreat (7.7 vs. 3.1). There were more modest differences in the average number of cooperative events (5.1 vs. 3.4). Still, there was a higher prevalence of cooperative events in countries where there was a democratic retreat. At first glance, this may seem counterintuitive. However, it demonstrates that in countries sliding toward political crisis, there are usually attempts to reverse the slide through cooperative acts. The fact that cooperative events were fairly similar in incidence in both retreat and no retreat cases accounts for the finding that most cooperative events were not statistically significantly associated with no retreat outcomes, and that several in fact were more commonly found in the no retreat cases.

Thus the answer to our first question is that there are observable differences in the frequencies of conflictual and cooperative events that can distinguish between the cases where democracy suffered a retreat and those where it did not. In particular, it is difference between the level of conflictual and cooperative events and actions that appears crucial.

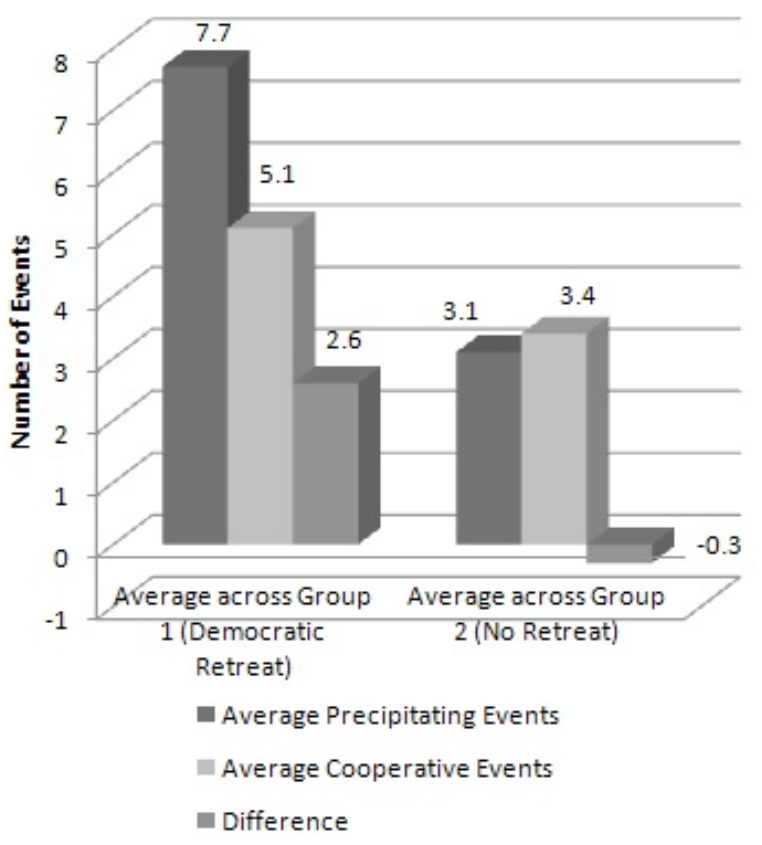

Figure 2: Frequency distribution of conflictprecipitating and cooperative events. 
It is where conflict-precipitating events occur considerably more often than cooperative events and actions that democracy will likely fail. On the other hand, where cooperative events balance closely or even slightly outweigh conflict-precipitating events, democracy is unlikely to retreat. Perhaps our most interesting finding is that it is not necessary for cooperative events to dominate, nor for conflict to be wholly absent, for democracy to prevail and continue. All that is necessary is for cooperative actions and events to fully balance conflictual events, and to avoid a strong imbalance in elite interactions and events in favor of conflict.

We go further to identify the most important such events and actions, and develop a regression model of their effects, in the following section.

In regard to our second question, the evidence clearly favors the theory of democracy as emerging from elites freely bargaining and maneuvering toward agreements, rather than being bound or strongly guided by prior institutional arrangements. In the no retreat cases, the numbers of cooperative and precipitating events were very nearly even, with cooperative events only slightly dominating. We therefore find no evidence that during these periods around national elections, prior existing institutions strongly restrained elites from conflictual actions. Rather, it appears that in a rough balance between cooperative and non-cooperative actions and events, the cooperative actions and events only slightly won out. Similarly, the retreat cases do not show a wholly unrestrained conflictual pattern of elite interactions. Rather, these cases show quite significant efforts by elites to work toward cooperation, with even more cooperative actions or events than in the no retreat cases (average 5.1 vs. 3.4 per case), that were in the end overwhelmed by even greater numbers of conflictual actions and events. It thus appears than an institutional theory of democratic success vs. failure does not fit our data, at least for the very short-term framework being investigated here (outcomes up to one year beyond the election). Rather, it seems that elites were constantly choosing and shifting between conflictual and cooperative approaches, and that stable resolutions reflected a very narrow triumph of cooperative choices.

The cases of Thailand, Bulgaria, and Estonia illustrate how the frequency of, and gap between, conflict-precipitating and cooperative events can affect regime stability. Thailand is an extreme case of cooperation and conflict. There were 16 total events of cooperation and conflict during the two-year period under study (October 2004-2006, bracketing the April 2006 election). Of these, four were cooperative events and 12 were conflict-precipitating events. In early 2005, then Prime Minister Thaksin Shinawatra's Thai Rak Thai (TRT) Party won a major victory at the polls. The Democrat Party conceded defeat, sacking their party leader. Yet instead of working within the political system, with this new mandate Thaksin began to consolidate power in the executive, and attempted to silence the media through the courts and through purchases of media outlets. Thaksin's cabinet approved a special decree-"The Emergency Powers Act"-that gave Thaksin sweeping powers to deal with Muslim separatists in Southern Thailand. His administration also put on trial individuals who criticized the government.

The opposition Democrats and their allies reacted strongly to these actions, pressuring the government through means outside of the system of political cooperation, such as bomb plots and street protests, to give up its attempts to consolidate power and control the media. There were few attempts at elite cooperation. One came during the height of antigovernment protest marches when Thaksin signaled that he would step down and not run again if protest leaders agreed to end street protests. This act of cooperation was isolated and was not followed up by other signals of cooperation and compromise. A distrusting Democrat Party boycotted the 2 April 2006 election, resulting in the TRT being able to grab most of the seats in the parliament. With an absolute majority in the parliament, Thaksin took on the power of the military, seeking to undermine senior officers. But the military struck back-in October 2006 he was ousted in a coup, thus producing a democratic retreat.

Bulgaria shows a different pattern. As a loss for the ruling BSP party seemed imminent in the presidential and parliamentary elections scheduled for 1997, marked instances of conflict arose. However in light of widespread public protests, the ruling party bowed to pressure and refrained from forming a new cabinet and instead allowed a caretaker government to take over until the parliamentary elections were over. The government eventually stepped down and allowed the opposition party UDF to take over the reins of government. Thus, the country was able to avoid retreat due to a prevalence of cooperative events which allowed for a smooth transition of power.

Estonia provides a case where retreat could have happened, given that the legislature passed a noconfidence motion in 1994 against the reigning Prime Minister Mart Laar, who was forced to step down and allow Andres Tarand to take over. However, the country surprisingly saw no conflict-precipitating events on the part of the ruling regime or the opposition. Instead the 1995 elections were allowed to take place and the opposition party KMU won, eventually forming a coalition government with the Centre Party.

While the frequency of cooperative and precipitating events and the gaps between them are important factors in democratic retreat, there may also be a pattern in how elite interactions unfold within a particular election period that may be important for understanding regime outcomes. That is, do cooperative and conflictual events tend to cluster together, and does one type tend to have a higher event density than the other? To explore this, an event density 
score was calculated for each country to understand what effect, if any, event clustering had on regime stability [30]. Figure 3 illustrates the results of the examination of event clustering.

The average cluster value of events for the democratic retreat cases was 0.81 , whereas the average cluster size for cases in which there was no democratic retreat was 0.73 . So in both cases, all events tended to occur in clusters, rather than as isolated incidents.

In distinguishing between retreat and no retreat cases, the cluster analysis follows the same pattern as the event counts-it is the difference between precipitating and cooperative events that matters. The cluster value for cooperative events is about the same for both retreat and no retreat cases (0.69 vs. 0.67). However, in the cases of democratic retreat the clustering value for conflict-precipitating events is higher than for cooperative events (0.75 vs. 0.69 ), while for the no retreat cases the clustering value for precipitating events is lower than for cooperative events (0.54 vs. 0.67). Thus we find a strong preponderance of density of cooperative events over precipitating events characterizes the no retreat cases; while a modest preponderance in the density of precipitating events over cooperative events characterizes the cases of democratic retreat. This means that in either outcome, it is usually a series of events, rather than one specific event or action, that tilts the outcome and determines democratic retreat or stability.

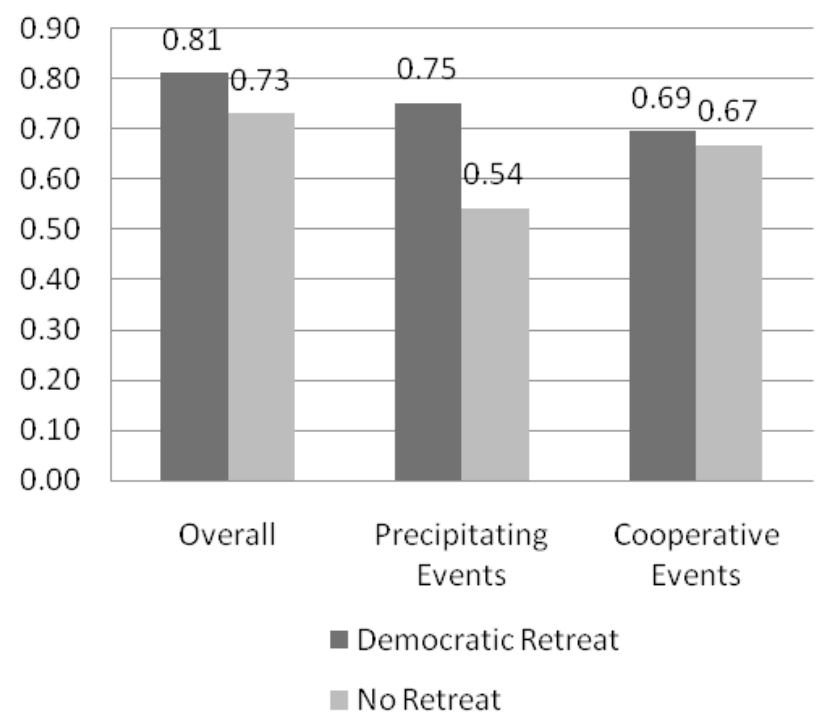

Figure 3: Cluster value results.

\subsection{Specific Variables and a Democratic Retreat Model}

The next stage in the analysis was to determine the relative impact of specific events and actions on democratic retreat or persistence. We did this by conducting a multivariate logistic regression, pooling all the cases and events [31]. The results showed four events were statistically significant. These were
BigWin, ConstStr, ContrlOpp, and VioActs. The regression model is depicted in Table 1 . The model had a $0.5 R^{2}$ value.

Table 1: Four variable logistic model.

\begin{tabular}{ccc}
\hline Indep. Var. & Odds Ratio & Std. Err. \\
\hline BigWin & 0.063 & $(0.076)^{* *}$ \\
ConstStr & 3.306 & $(2.229)^{*}$ \\
ContrlOpp & 1.709 & $(0.455)^{* *}$ \\
VioActs & 7.099 & $(4.868)^{* * *}$ \\
\hline
\end{tabular}

Note: Entries are based on unstandardized parameter estimates in logistic regression equations for the cases in our sample. Standard errors are depicted in parentheses. $* \mathrm{p}<0.1$; $* * \mathrm{p}<0.05 ; * * * \mathrm{p}<0.01$

The odds ratios indicate that in our sample an incidence of event BigWin sharply decreases the relative odds of a democratic retreat by approximately $94 \%$. Evidently, a decisive victory in an election that is considered free and fair gives the winning party sufficient standing to deal with opponents from a position of security. It may also deprive opposition elites of the strength to keep contesting the regime's right to hold power. Conversely, the incidence of event ContrlOpp increases the relative odds of a democratic retreat by $70 \%$. Thus, regimes that are willing to place significant new restrictions on opponents in the run-up to elections are well on their way to a full retreat from democratic government. Another way that governments restrict opponents is through changes to the constitution. An incident of ConstStr raises the relative odds of democratic reversal by $230 \%$, more than twice as much as an incident of ContrlOpp. The strongest effect is from an incident of VioActs; this increases the relative odds of a democratic retreat by roughly $610 \%$, more than twice as much as constitutional struggles. Violence by the opposition (not the government, which is MilExt) either in the run-up, or immediately following, national elections seems to give the ruling regime an opportunity to suppress the opposition and retreat from democracy in the name of security. It may also be a signal that the opposition believes the regime is not giving it a fair opportunity in the elections, and therefore has to pursue its aims by direct attacks on the government.

The probability of a democratic retreat was predicted for each of the countries in the analysis using the logistic regression. The model correctly predicted no retreat in $89.66 \%$ of the cases that remained democratic and correctly predicted retreat in $78.57 \%$ of the cases that experienced a significant retreat.

\subsection{Patterns of Regime-Opposition Interactions}

We further explored, through factor analysis, the possibility that our events and actions fell into 
patterns of cooperative and precipitating events. Such composite factors might characterize common trajectories that lead to democratic retreat or stability. For our paper we use principal component factor analysis. From a factor rotation with up to 5 factors, a possible three-factor solution emerged. This threefactor solution is outlined in Table 2 along with the factor score coefficients for each of those variables. The factor coefficients indicate that each factor is composed of roughly equal weighting on its component variables.

New composite variables were created by combining the variables in each factor. These were: Factor 1Violence, Intervention and Negotiation; Factor 2Elections and Policy; and Factor 3-Ruling Party Actions. The factor score method was used (factor scales are preferred for binary data). Individually the variance for Factor 1 is 2.42, variance for Factor 2 is 2.22, and variance for Factor 3 is 2.16. A logistic regression was conducted using the factor scores. Table 3 illustrates the results of the regression. The model had a $0.25 R^{2}$ value.

An increase in Factor 1: Violence, Intervention and Negotiation (VioActs, IntPres and ExpNeg) increased the relative odds of democratic retreat. Factor 1 can be thought of as indicating a process in which violent acts-usually a guerrilla war or acts of terrorism-on the part of the opposition result in international pressure, which then brings parties to the negotiation table. However, this pattern of international pressure and explicit negotiation in conjunction with violent opposition actions had a negative impact on democratic stability.

This pattern is exemplified by the politics of CongoBrazzaville between 1996 and 1998. In July 1996, armed militias loyal to former President and opposition leader Denis Sassou-Nguesso occupied the northeastern town of Mossaka to prevent the installation of the new mayor Jean-Michel BokambaYangoma, a member of the presidential group, who had defeated an opposition candidate close to SassouNguesso in recent mayoral elections. Over the next year, the conflict descended into Civil War, as the regime, led by democratically elected president Pascal Lissouba, and the opposition engaged in large scale tit-for-tat violence. In June of 1997, President Jacques Chirac of France appealed personally to Lissouba and Sassou-Nguesso to end hostilities. Both factions engaged in explicit negotiations, including ceasefires and UN and African Union sponsored peace talks. These efforts ultimately failed when a coup took place in October 1997, orchestrated by former president Sassou-Nguesso.

Yet this process of violence, international pressure and negotiation is just one possible route of the political process.

Table 2: Three-factor solution.

\begin{tabular}{|c|c|c|c|}
\hline \multicolumn{2}{|c|}{ Factor/Label } & Variable & Coefficient \\
\hline \multirow{3}{*}{ Factor 1} & ExpINeg & $\begin{array}{l}\text { Explicit negotiations between government and opposition } \\
\text { leaders to resolve disputes. }\end{array}$ & 0.301 \\
\hline & IntPres & $\begin{array}{l}\text { International pressure on competing political leaders or } \\
\text { parties for reconciliation and fair play. }\end{array}$ & 0.260 \\
\hline & VioActs & Guerrilla or terrorist acts by the opposition. & 0.352 \\
\hline \multirow{4}{*}{ Factor 2} & BigWin & $\begin{array}{l}\text { A free and fair election that produces a large majority in favor } \\
\text { of one party. }\end{array}$ & 0.297 \\
\hline & StepDown & $\begin{array}{l}\text { Willingness of a government leader to step down (whether } \\
\text { because of term limits, retirement or electoral defeat). }\end{array}$ & 0.255 \\
\hline & OppCont & $\begin{array}{l}\text { Evidence that the opposition will successfully contest for } \\
\text { power. }\end{array}$ & 0.253 \\
\hline & NewPol & $\begin{array}{l}\text { New policy departures by a civilian regime where the military } \\
\text { is strong and concerned. }\end{array}$ & 0.269 \\
\hline \multirow{4}{*}{ Factor 3} & ActOnOpp & $\begin{array}{l}\text { Concession or agreement by government leaders to accept or } \\
\text { act on opposition demands. }\end{array}$ & 0.330 \\
\hline & NoAction & $\begin{array}{l}\text { Popular pressure by riots or demonstrations combined with an } \\
\text { indecisive or inactive regime. }\end{array}$ & 0.324 \\
\hline & ConstStr & $\begin{array}{l}\text { Constitutional struggles in which groups contest key rules of } \\
\text { the game, challenging or seeking to change the constitution. }\end{array}$ & 0.322 \\
\hline & ContrlOpp & $\begin{array}{l}\text { Coercive acts by the regime to undermine or hinder the } \\
\text { opposition from fairly contesting an election. }\end{array}$ & 0.292 \\
\hline
\end{tabular}


Table 3: Three factor logistic regression.

\begin{tabular}{ccc}
\hline $\begin{array}{c}\text { Independent } \\
\text { Variable }\end{array}$ & Odds Ratio & Std. Err. \\
\hline Factor 1 & 2.267 & $(0.92)^{*}$ \\
Factor 2 & 0.519 & $(0.23)$ \\
Factor 3 & 2.701 & $(1.12)^{*}$ \\
\hline
\end{tabular}

Note: Entries are based on unstandardized parameter estimates in logistic regression equations for the cases in our sample. Standard errors are depicted in parentheses. $* p<0.05$

Instead of using violence, the opposition could pressure the regime through non-violent action [32]. The international community could decide that pressure alone is insufficient to thwart a political crisis and intervene directly in the election, and the opposition could choose constitutional and peaceful means, instead of violence, to protest regime repression. A number of potential pathways of political conflict are illustrated in Appendix 3.

Factor 2: Elections and Policy (OppCont, BigWin, StepDown, NewPol) demonstrates a pattern of events and actions that had substantial positive effects on democratic survival. This result is in accord with expectations since it reflects an environment of political competition in which both sides respect the process and are willing to accept the results of elections. That is, the opponents are able to effectively contend for power, one side scores a clear and decisive victory in elections, and the losing party steps down from power while civilian leaders create new policies to diminish the military's role.

This process occurred in Bulgaria during the 1996 presidential election. In the run up to the election, polls indicated that the UDF opposition coalition candidate Peter Stoyanov had a good chance of winning the presidential election. The election resulted in Stoyanov winning $59.9 \%$ of votes. Prime Minister (PM) and ruling party leader Zhan Videnov agreed to step down as both PM and party leader. In April, 1997, the UDF won a decisive parliamentary election. During this period there were no regime actions to control the opposition or prevent them from fairly contesting the election.

The case of Bulgaria shows that while partial democratic regimes sometimes tip the scales in their favor, they may choose not to overtly suppress the opposition. Instead, democratic consolidation is advanced if the regime displays a willingness to compete for political power within the political system. There are other options open to both the opposition and ruling regime along the way that would set the country on a different course. For example, once the ruling regime saw that the opposition was running a strong campaign, they could decide to suppress them. And if the opposition wins, the ruling party could refuse to step down, resulting in the failure of democracy (see Appendix 3). Factor 2 shows the positive power of this cluster of cooperative events and actions to preserve democratic institutions.

Factor 3: Ruling Party Action (ActOnOpp, NoAction, ConstStr, ContrlOpp) represents the opposite pattern-a cluster of conflict-precipitating events and actions-and had the largest impact on the odds of democratic retreat. Factor 3 reflects an option-choice framework. In this scenario the opposition is active, and the regime considers them a threat. The regime chooses from several options-give in to opposition demands, ignore them, or suppress the opposition using a change in the constitutional rules or forcesometimes using all of these options in the lead-up to an election. The presence of the latter three variables in the factor indicates a choice to deal with the opposition by constraining them rather than engaging with the opposition. ContrlOpp and ConstStr reflect the suppression of new groups and changing of the rules of the game to benefit the ruling coalition. Thus the third factor runs the spectrum of responses from conciliation, to ignoring, to actively suppressing the opposition.

Albania seems to exemplify this pattern. In Albania there were multiple instances in which the regime tampered with the constitutional and legal system. These included dismissing the head of the Supreme Court, barring officials that had served under the erstwhile Communist regime, and the passage of new laws requiring screening of public officials' activities under the communist regime. Among many political arrests and prosecutions, the ruling party convicted the leader of the Albanian Socialist Party on dubious grounds and the police on numerous occasions broke up meetings of the opposition party PSS. Under intense international pressure, an attempt was made by the major parties to come to the negotiating table and the ruling party did eventually agree to several of the opposition demands. Nonetheless, Albania's democracy still experienced a sharp retreat.

The factor analysis does not provide a superior model for forecasting democratic outcomes across the entire data set. This is because these particular clusters only occur in some of the cases; better results are obtained with the four variable logistic regression shown in Table 1, as these particular events are found more commonly across the cases. However, the factor analysis does show that certain of our events and actions do tend to align together in characteristic patterns.

The pathways to these patterns are indicated in Appendix 3. This figure shows how many 'decision points' we found where elites could choose cooperative or conflictual interactions. We do not rule out the fact that once a democracy becomes consolidated these choices become institutionalized or rule-bound, so that in established democracies, certain choices (e.g. banning an opposition party or using extreme military force against political opponents) become unthinkable, and cooperative events completely dominate. Our analysis of the events around elections 
in emerging democracies, however, shows how often both conflictual and cooperative events arose. Clearly, a theory of elite interactions that involves a high degree of elite choice, and outcomes that, in the near term, depend on whether the preponderance of those choices leans toward cooperation or conflict, best fits the conditions in emerging, partial democracies.

\section{Conclusions}

This paper provides significant evidence for the importance of elite interactions in the development of democratic stability and retreat. An analysis of the total numbers of events across two groups of countries with different outcomes revealed that the observed incidence of elite interactions and events in a precipitating or cooperative direction in the months around national elections is crucial in determining those outcomes.

The logistic regression analysis bears out our hypothesis that specific actions and events can predict, at least for the short term, whether an election will lead to the continuation or ending of progress toward democracy. The four variable model identified democratic retreat and democratic continuance for the cases in this data set approximately $79 \%$ and $90 \%$ of the time, respectively. A key finding is that we generally do not see a simple pattern of all cooperative events and actions in successes vs. all conflictprecipitating events and actions in failures. Rather, in all our observed emerging democratic countries we see a combination of cooperative and conflictual events/actions around elections; what differs is the balance and specific combinations of events and actions. A significantly higher incidence of precipitating events, such as violent acts by the opposition, control of the opposition through overt repression, and control of the opposition through manipulation of the constitutional rules is indicative of a failure on the part of the ruling coalition to keep up its commitments toward withholding violence, maintaining stability and sharing political and economic power with new claimants. Conversely, a preponderance of cooperative actions indicates a willingness to keep to commitments to "play by the rules" and indicates a high probability that democratic institutions will endure.

In cases of democratic retreat it is not just that the total number of conflict-precipitating events and actions is higher than in cases of democratic survival; rather, it is the difference between that number and the number of cooperative events that is most significant. On average, there were $66 \%$ more precipitating than cooperative events in cases of democratic retreat, whereas there were $11 \%$ fewer precipitating events than cooperative events in cases in which there was no retreat from democracy. The clustering analysis revealed that there is a greater concentration of precipitating events in cases of democratic retreat than in cases in which a retreat did not take place.
However, the clustering of cooperative events was similar across both groups of cases. This means that in retreat cases there was, within a short time, a flurry of concentrated conflict events that was not balanced by a similar concentration of cooperative events to counteract the damage to democracy.

It should be pointed out that it is the total balance of events over a sustained period around an election that matters. Observing several cooperative events in the run-up to an election is hopeful, but not sufficient, as a flurry of conflictual events may arise soon after the election, derailing that progress. This appears to have been the case in the recent elections in Egypt, where cooperative events marked the months before the Presidential election, but shortly afterward constitutional struggles, boycotts, and actions to control the opposition arose.

An analysis of which events happened most frequently provides the first clues in understanding democratic retreat. The very high incidence of the conflictual events control the opposition through overt repression (ContrlOpp) and political acts by the opposition to undermine an election or the ruling regime (OppActs) in the retreat cases indicates that the opposition was fairly strong and that the government was repressive. This conclusion is consistent with the social movement literature on repression and mobilization, which points to regime repression being most severe in circumstances where the opposition is well organized and possesses significant resources [33].

Conversely, the prevalence of the cooperative events bringing the opposition into the government (BringOpp) and a free and fair election that produces a big win at the polls (BigWin) in the no retreat cases indicates that it often takes explicit initiatives on the part of regimes to follow democratic processes and to allow the opposition a role in the political process to ensure democratic outcomes. It should be noted that not all countries in the no retreat group allowed free and fair elections to take place. In cases like Cameroon and Tunisia, the opposition chose to boycott the elections and there were serious doubts about the validity of the results. But elections did take place and most importantly, the ruling party was able to maintain power without resorting to violent suppression of the opposition and the opposition itself was not very vocal or used less overt protest tactics. Such cases may not be ideal in terms of democratic practice, but they avoided the coups, cancelled elections, and suppression of opposition that mark major retreats or endings of democratic processes.

We also wish to highlight our findings regarding international intervention. These clearly show that international pressures cannot substitute for the willingness of domestic elites to engage in cooperative actions or create cooperative events. We found that both international engagement variables were observed more often in cases of democratic retreat. In fact, either international pressure to promote recon- 
ciliation and fair play (IntPres) or intervention to promote free and fair elections (Interv) occurred in 9 of the 14 cases of democratic retreat. Of the 10 cases where IntPress was observed, 6 of the 10 ended in democratic retreat. IntPres was also significant in the factor analysis, where it occurred as part the factor leading to democratic retreat (Factor 1).

While this may be a case of the international community getting involved in only those cases where there is extreme violence and thus the highest risk of democratic retreat, it might also be that international involvement has unintended consequences. One possibility is that international involvement alters the factional power balance by pressuring the regime to negotiate, and this emboldens the opposition by creating a political opportunity that may lead to more overt and confrontational protest tactics and increased mobilization. The message sent by international involvement may be that the regime cannot maintain peace alone or that the international community disapproves of its actions toward the opposition. The opposition exploits this message, thereby "upping the ante". International pressure then can do more harm than good.

Where the regime is unable or unwilling to signal

\section{References and Notes}

1. Goldstone JA, Bates R, Epstein D, Lustik $M$, Marshall M, Ulfelder J, Woodward M. A Global Model for Forecasting Political Instability. American Journal of Political Science. 2010;54(1):190-208.

2. Mansfield ED, Snyder JL. The Sequencing Fallacy. Journal of Democracy. 2007;18(3):5-9.

3. Higley J, Burton M. Elite Foundations of Liberal Democracy. Lanham, MD, USA: Rowman \& Littlefield; 2006.

4. Linz J, Stepan A. Problems of Democratic Transition and Consolidation. Baltimore, MD, USA: Johns Hopkins University Press; 1996.

5. Linz J, Stepan A. Toward Consolidated Democracies. In: Diamond L, Plattner MF, editors. The Global Divergence of Democracies. Baltimore, MD, USA: Johns Hopkins University Press; 2001.

6. Przeworski A, Alvarez ME, Cheibub JA, Limongi F. Democracy and Development: Political Institutions and Well-Being in the World, 1950-1990. New York, NY, USA: Cambridge University Press; 2000.

7. Tilly C. Regimes and Repertoires. Chicago, IL, USA: The University of Chicago Press; 2006.

8. Diamond L. Thinking about Hybrid Regimes. Journal of Democracy. 2002;13(2):21-35.

9. O'Donnell G, Schmitter P. Transitions from Authoritarian Rule: Tentative Conclusions about Uncertain Regimes, Vol. 4. Baltimore, MD, USA: Johns Hopkins University Press; 1986.

10. Fearon J, Laitin D. Ethnicity, Insurgency, and Civil War. American Political Science Review. its willingness to cooperate or compromise, international involvement cannot make up for this absence. International pressures thus only seem likely to contribute to democratic progress where the international actors have sufficient leverage to get the regime and opponents to engage in cooperative actions themselves, such as direct negotiations, stepping down, and abiding by election results.

A final conclusion from this analysis is that it is a worthwhile endeavor to further develop event-count analysis to understand conflict trends (cf. [34]). The fact that many events had strong and significant relationships with democratic retreat and that there were several common patterns of conflict and cooperation is an encouraging sign in the study of event patterns as antecedents to political conflict and democratic collapse.

\section{Acknowledgements}

We gratefully acknowledge that this paper was made possible with funding from the United States Institute of Peace. We also extend thanks to the anonymous reviewers, whose suggestions greatly strengthened the paper.

2003;97(1):75-90.

11. Mansfield ED, Snyder, JL. Democratic Transitions, Institutional Strength, and War. International Organization. 2002;56(2):297-337.

12. Acemoglu D, Robinson JA. A Theory of Political Transitions. The American Economic Review. 2001;91(4):938-963.

13. Acemoglu D, Robinson JA. Economic Origins of Dictatorship and Democracy. New York, NY, USA: Cambridge University Press; 2006.

14. North D, Wallis J, Weingast B. Violence and Social Orders: A Conceptual Framework for Interpreting Recorded Human History. Cambridge, UK: Cambridge University Press; 2009.

15. Lee SJ. Democratization and polarization in Korean society. Asian Perspective. 2005;29(3):99-125.

16. LeBas A. Polarization as Craft: Party Formation and State Violence in Zimbabwe. Comparative Politics. 2006;38(4):419-438.

17. Layman GC, Carsey TM, Horowitz JM. Party polarization in American politics: Characteristics, causes, and consequences. Annual Review of Political Science. 2006;9(June):83-110.

18. Goldstone JA, Ulfelder J. How to Construct Stable Democracies. The Washington Quarterly. 2004;28(1):9-20.

19. Rueschemeyer D, Stephens EH, Stephens JD. Capitalist Development and Democracy. Chicago, IL, USA: University of Chicago Press; 1993.

20. Moore Jr B. Social Origins of Dictatorship and Democracy: Lord and Peasant in the Making of the Modern World. Boston, MA, USA: Beacon Press; 1966. 
21. Skocpol T. States and Social Revolutions. Cambridge, UK: Cambridge University Press; 1979.

22. Sartori G. Parties and Party Systems. Cambridge, UK: Cambridge University Press; 1976.

23. Marshall MG. Political Conflict, Measurement of. In: Kempf-Leonard K, editor. Encyclopedia of Social Measurement. San Diego, CA, USA: Academic Press; 2004.

24. Keefer $P$, Knack S. Polarization, Politics, and Property rights. Washington, DC, USA: The World Bank; 2000.

25. North DC, Wallis JJ, Weingast BR. Violence and Social Orders: A Conceptual Framework for Interpreting Recorded Human History. Cambridge: Cambridge University Press; 2009.

26. Acemoglu D, Johnson S, Robinson JA. The Rise of Europe: Atlantic Trade, Institutional Change and Economic Growth. 2005;95(3):546-579.

27. Glaeser EL, LaPorta R, Lopez-de-Silanes F, Shleifer A. Do Institutions Cause Growth? Journal of Economic Growth. 2004;9(3):271-303.

28. A timeline of observed events for each case is available from the authors online from: http://jackgold stone.gmu.edu/replication-data-forecasting-stability-or -retreat-in-emeging-democratic-regimes/

29. Center for Global Policy. Political Instability Task Force Consolidated Problem Set. 2011. Available from: http://www.systemicpeace.org/inscr/PITF\%20C onsolidated\%20Case\%20List2011.pdf (accessed on 24 April 2013).

30. Event density measures the clustering of precipitating and cooperative events. We looked at the full two-year period (18 months preceding an election to 6 months following the election). The equation used was a numerator of the total number of observed events minus the number of isolated events and the denominator was the total number of observed events. Isolated events were defined as those that did not have another event occurring during the month or in the month prior or following. A cluster density of close to 1 indicates events were very densely clustered while a density of close to 0 indicates that events were very spread out.

31. According to Peng, Less and Ingersoll (2002) "logistic regression is well suited for describing and testing hypotheses about relationships between a categorical outcome variable and one or more categorical or continuous predictor variables". In this case, the variables under study are in the form of count data that list the number of occurrences of cooperative and precipitating events and the dichotomous dependent variables of democratic outcome ( $1=$ retreat, $0=$ no retreat). See Peng CYJ, Lee $\mathrm{KL}$, Ingersoll $\mathrm{GM}$. An Introduction to Logistic Regression. Journal of Educational Research. 2002;96(1):3-14.

32. Chenoweth E, Stephan M. Why Civil Resistance Works: The Strategic Logic of Nonviolent Conflict. New York, NY, USA: Columbia University Press; 2011.

33. Davenport C, Johnston $H$, Mueller C. Repression and Mobilization. Minneapolis, MN, USA: University of Minnesota Press; 2005.

34. Schrodt PA. Event Data in Foreign Policy Analysis. In: Neack L, Hey JAK, Haney PJ, editors. Foreign Policy Analysis: Continuity and Change. New York, NY, USA: Prentice-Hall; 1994. 
Appendix 1: Countries and time periods studied.

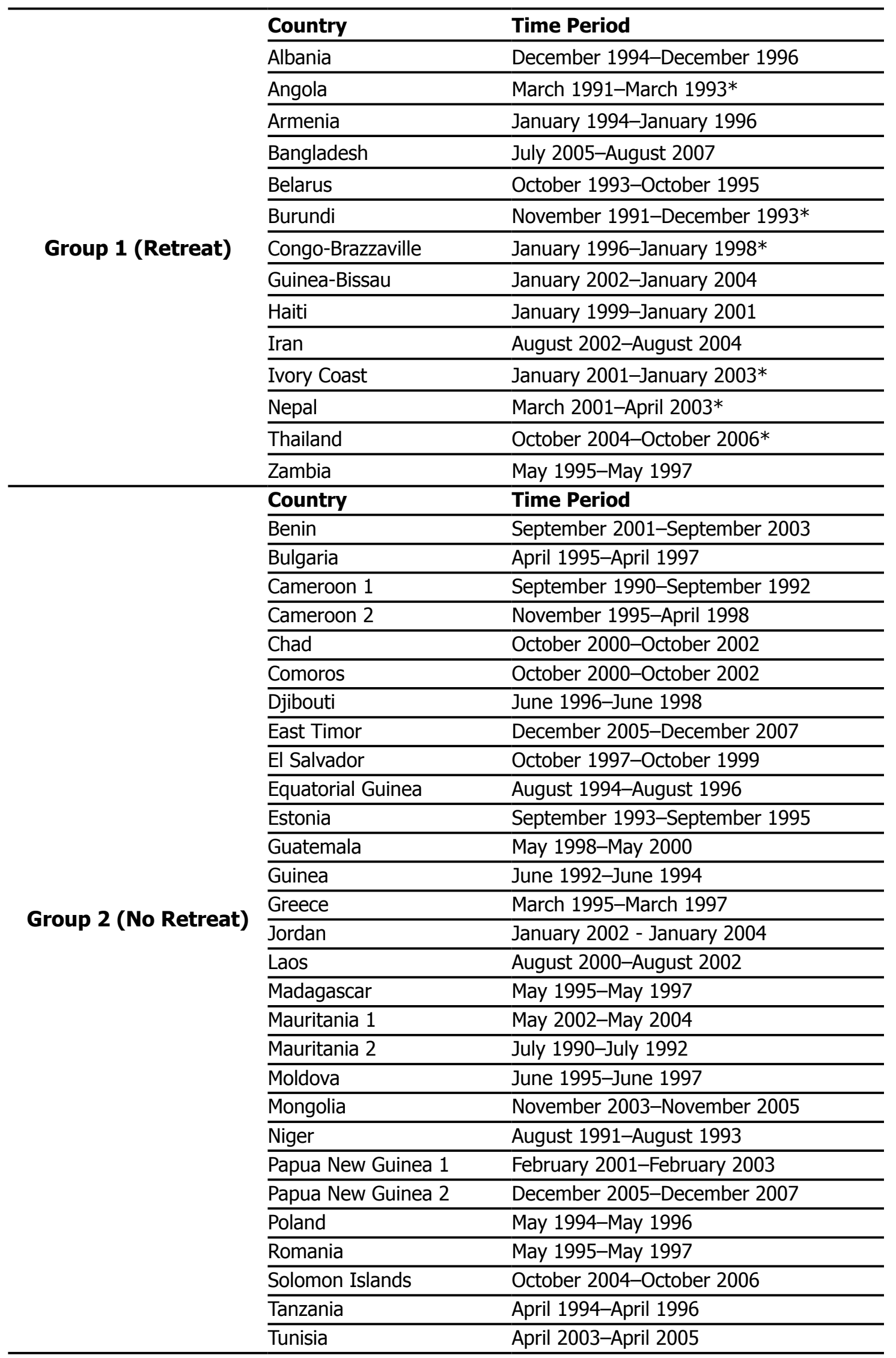

*Civil war started, resumed, or intensified during this period 
Appendix 2: Full typology of elite interaction events.

\begin{tabular}{|c|c|}
\hline Precipitating Events & Abbreviation \\
\hline Evidence that the opposition will successfully contest for power. & OppContes \\
\hline $\begin{array}{l}\text { New policy departures by a civilian regime where the military is strong } \\
\text { and concerned. }\end{array}$ & NewPol \\
\hline $\begin{array}{l}\text { Popular pressure by riots or demonstrations combined with an } \\
\text { indecisive or inactive regime. }\end{array}$ & NoAction \\
\hline $\begin{array}{l}\text { Constitutional struggles in which groups clearly differ in their } \\
\text { interpretation, or their efforts to change, basic rules that define access } \\
\text { to power and how it is exercised. }\end{array}$ & ConstStr \\
\hline $\begin{array}{l}\text { Military actions against a guerrilla rebellion, peaceful protest, opposition } \\
\text { party or activists, where the actions are extreme and clearly violate } \\
\text { democratic and human rights norms. }\end{array}$ & MilExt \\
\hline Military threats or actions against the government. & MilThreat \\
\hline $\begin{array}{l}\text { A victory by a political party whose policy platform is viewed as } \\
\text { threatening to ruling elite interests. }\end{array}$ & RefVic \\
\hline $\begin{array}{l}\text { Coercive acts by the regime to undermine or hinder the opposition from } \\
\text { fairly contesting an election. }\end{array}$ & ContrlOpp \\
\hline $\begin{array}{l}\text { Political acts by the opposition to undermine elections or the ruling } \\
\text { regime. }\end{array}$ & OppActs \\
\hline $\begin{array}{l}\text { Acts by other nations that affect the regime or opposition in terms of } \\
\text { their resources or capabilities for political actions. }\end{array}$ & IntActs \\
\hline Guerrilla or terrorist acts by the opposition. & VioActs \\
\hline Cooperative Events & Abbreviation \\
\hline $\begin{array}{l}\text { Bringing opposition political leaders into the cabinet or executive } \\
\text { position or leading roles in the legislature. }\end{array}$ & BringOpp \\
\hline $\begin{array}{l}\text { Agreement by the government or opposition to accept defeat in a free } \\
\text { and fair election. }\end{array}$ & AccptDef \\
\hline $\begin{array}{l}\text { A free and fair election that produces a large majority in favor of one } \\
\text { party. }\end{array}$ & BigWin \\
\hline $\begin{array}{l}\text { Popular support or acceptance for measures by the government to deal } \\
\text { with an unruly opposition. }\end{array}$ & PopSupp \\
\hline $\begin{array}{l}\text { Concession or agreement by government leaders to accept or act on } \\
\text { opposition demands. }\end{array}$ & ActOnOpp \\
\hline $\begin{array}{l}\text { Explicit negotiations between government and opposition leaders to } \\
\text { resolve disputes. }\end{array}$ & ExplNeg \\
\hline International intervention to promote free and fair elections. & Interv \\
\hline $\begin{array}{l}\text { Willingness of a government leader to step down (whether because of } \\
\text { term limits, retirement, or electoral defeat). }\end{array}$ & StepDown \\
\hline $\begin{array}{l}\text { The natural or accidental death of government or opposition leaders } \\
\text { who were especially fractious or polarizing. }\end{array}$ & LedDeath \\
\hline $\begin{array}{l}\text { International pressure on competing political leaders or parties for } \\
\text { reconciliation and fair play. }\end{array}$ & IntPres \\
\hline Government lifts ban on some type of political activity. & LiftBan \\
\hline $\begin{array}{l}\text { Government, dominant party or leader publicly accepts a } \\
\text { that weakens their political position. }\end{array}$ & AccRulg \\
\hline
\end{tabular}


Appendix 3: Flowchart of intra-elite maneuvering.

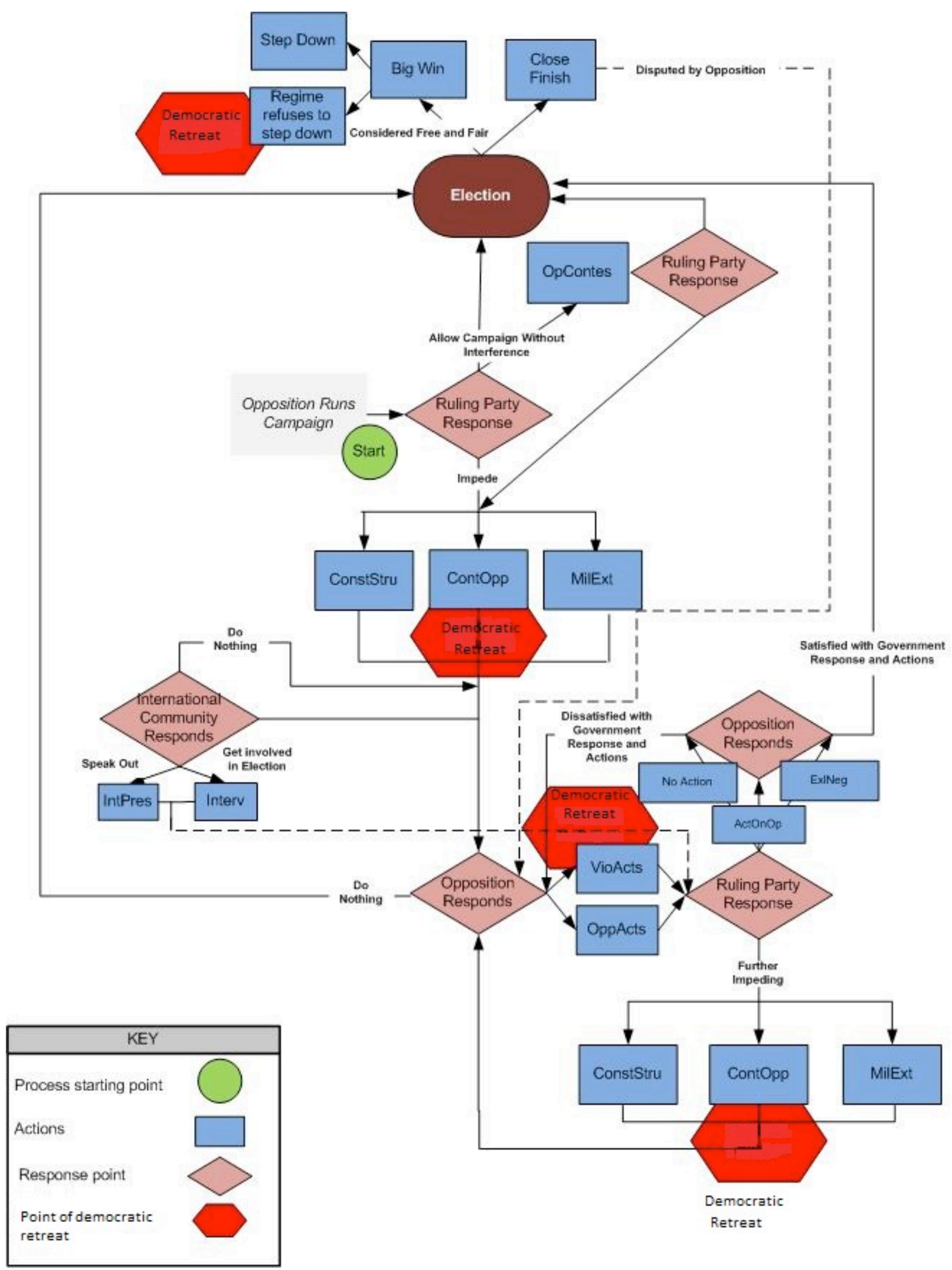

